\title{
The Effect of Youtube Advertisement on Consumer Purchase Intention of Online Transportation Brands in Bandung (Case Study on Grab and Gojek Companies)
}

\author{
Mahir Pradana*, Irfan \\ Business Administration International Program School of Communication and Business Telkom University, Indonesia \\ *Corresponding Author \\ Mahir Pradana \\ Article History \\ Received: 16.03.2021 \\ Accepted: 24.04.2021 \\ Published: 30.04.2021

\begin{abstract}
Purchase intention is defined as the level where consumers have a positive attitude towards a brand and have a commitment and tend to continue to buy products with certain brands in the future. The method used in this research is to use quantitative methods. Based on the results of research and discussion on this research are Youtube advertisements on customers of Gojek and Grab transportation in Bandung city is in the good category. Youtube advertisements and purchase intention has a low level of correlation and a coefficient of determination but it is estimated that per unit increase in youtube advertisements variable, it will increase in the purchase intention variable based on regression model. Keywords: Youtube, Purchase Interest, Online Transportation, Communication.
\end{abstract}

\section{INTRODUCTION}

Along with the times, human needs show a significant increase. Both from daily needs and to meet other needs. Likewise, with an increase in the number of businesses which are increasing day by day. Therefore, currently businesspeople are competing to create competitive strategies that can attract consumers. Moreover, with the support of technological developments and information that are increasingly being used by businesspeople.

Technology and information are one of the basic needs of its users, especially the internet, providing opportunities for businesspeople to take advantage of the internet base as a strategy to attract consumers. In addition, the transportation system also shows the use of the internet base, this development can be seen from the presence of companies using changes in transportation systems from conventional to online transportation which are currently being discussed.

Transportation in general can be defined as an effort to move people or goods from a location, which is called the location of origin, to another location which is usually called the destination location for certain purposes by using certain tools as well [1]. Meanwhile, online transportation can be interpreted as a tool for moving people or goods that are moved by human power from one place to another by using online applications.

The development of online business, including online transportation, is currently in great demand by businesspeople and has mushroomed in the community. Apart from being able to reduce the cost of promoting the use of online bases, it is also seeing the current phenomenon, in which most people, especially in Indonesia, cannot be separated from the internet. The development of service companies engaged in online transportation shows that many consumers give positive appreciation to online transportation. Starting from the presence of the local company Go-jek in 2010 through telephone calls, until now it has used an online application. Followed by Uber, which is a company from the United States and Grab, which is a company from Singapore. The three of them are companies in similar fields and are among the top in their business. There are many more service companies in the online transportation business apart from those that the researchers have mentioned, but of the many online companies, these three companies are the ones that are being looked at by many people today.

Copyright (C) 2021 The Author(s): This is an open-access article distributed under the terms of the Creative Commons Attribution 4.0 International License (CC BY-NC 4.0) which permits unrestricted use, distribution, and reproduction in any medium for non-commercial use provided the original author and source are credited. 
The Grab Company, originally called GrabTaxi, is an online transportation company from Singapore founded by Anthony Tan from Malaysia. Grab was founded in 2012 and has spread across several countries in Southeast Asia. Grab is Southeast Asia's leading ride-hailing and mobile payments platform that seeks to answer some of the most crucial transportation challenges and bring transportation freedom to 620 million people in Southeast Asia. Grab's main products include driving solutions for drivers and passengers that emphasize speed, safety, and certainty, as stated in the official link. Currently Grab has several products, one of which is GrabCar, where GrabCar is a private car booking service that can be rented to travel from one place to another.

The development of technology and information makes consumers more critical in choosing the service products they will enjoy. For businesses, customer satisfaction is seen as a dimension of market performance. Consumer satisfaction describes the performance of the products that consumers consume, related to the expectations of these consumers. In choosing products, consumers form expectations about the value and satisfaction that will be given to the product and buy according to those expectations. Satisfied consumers will make repeat purchases and will provide information about their experiences to other consumers, but on the other hand, if they experience dissatisfaction, they will choose products from competitors. This satisfaction is what will encourage consumers to become customers in these products.

Grab Company is one of the companies that is trying to maintain its existence in several parts of Southeast Asia by making various innovations. This can be seen from the download of the Grab application, which is free of high fees, in a condition that has just entered the Indonesian

Market, preceded by Go Jek as a local company.

Table-1: Number of Online Transportation

\begin{tabular}{|l|l|l|l|l|}
\hline No & Name & Total & Number of Rating & Information \\
\hline 1 & Gojek & 50 Million & 4.2 & According to Playstore \\
\hline 2 & Grab & 100 Million & 4.4 & According to Playstore \\
\hline
\end{tabular}

Resource: Playstore (Data collected by researchers (2020)

Based on the data above, the number of downloaders of the Grab application shows the first rank and after that is Gojek and has the highest number of ratings among the two. This shows that Grab can compete with good achievements. In this study, researchers took the Grab Company as the research object. Considering the large number of consumer interest in Grab, it can be seen from the downloader rating of the Grab application even though Grab is not the first online transportation company in Indonesia. Grab's achievements can also be seen from the data on Top Brand results, Grab is in the first position above Go-jek.

Bandung, as one of the largest cities in Indonesia, is participating in the development of the Grab Company. Coupled with the number of campuses that are considered to have good quality, Bandung is one of the destinations for studying. The development of technology and information encourages most people to want convenience in many ways, including driving. The existence of online transportation practically using an application on a smartphone provides its own interest for most of these people. For some people, with Grab, it makes driving easier for them. They prefer vehicles that make them feel comfortable and practical in their use compared to public transportation, which was previously the main vehicle for the community, another special thing is the ease of access to get it. Following are the results of a survey from YLKI regarding the reasons why people use it online transportation is compared with conventional transportation.

The YLKI survey results show various reasons for consumers choosing online transportation. Based on the figure, the price factor is a consideration for the majority of consumers with a percentage of $84.1 \%$, assuming online transportation is cheaper than conventional transportation rates, followed by reasons of being faster with a percentage of $81.9 \%$, then feeling comfortable with a percentage of $78.8 \%$ and the last reason for feeling safe with a percentage of $61.4 \%$. This assumption is in line with the survey conducted by YLKI regarding consumer perceptions of online transportation services, which showed that the online transportation service level was very good at $77.7 \%$ and only $0.4 \%$ stated it was not good.

This positive appreciation from consumers is certainly influenced by various things including consideration of customer value. Researchers conducted a preliminary research in the form of a mini survey of nine respondents who were people of Bandung City, Grab customers and had used the GrabCar service. The following is the rating given by the nine respondents after using Grab with the GrabCar service as a form of assessment of their satisfaction with the product.

The rapid development of science and communication technology has had a major impact on competition in the business field. In connection with the development of increasingly sophisticated communication technology, forms, patterns, and communication equipment have also changed. Communication can not only be done individually, but it is 
necessary to have one or more speaking partners. The use of media nowadays is also increasingly complex, for example there are radio, television, newspapers, internet, mass media, online media, and so on.

The media have undergone major transformations over the past decade. Recent statistics show that the number of people accessing the Internet exceeds two billion four hundred thousand, that is, $34 \%$ of the world's population [2]. In addition, one in seven people in the world have a Facebook profile and nearly four in five Internet users visit social media sites [3]. With a growing number of Internet and social media users around the world, it is essential for communications managers to understand online consumer behavior.

Consumers increasingly use social media sites to seek information and turn away from traditional media, such as television, radio and magazines. The advent of social media has transformed the traditional one-way way of communication into multi-dimensional, two-way, peer-to-peer communication. Social media platforms offer opportunities for customers to interact with other consumers; thus, the company is no longer the sole source of brand communications [4]. The social web is changing traditional marketing communications. Traditional brand communications that were previously controlled and managed by brand and marketing managers are gradually being shaped by consumers.

Business activity is a field that can be influenced by the large number of consumers who are interested in using the products that the company produces. One of the strategies used by online taxi companies today is to use advertisements that are displayed on YouTube, where currently many people use YouTube as a new medium of entertainment besides television. Ads on YouTube are considered effective in attracting subscribers because there are currently many YouTube users in Indonesia.

Youtube recorded the number of logged-in monthly users of 1.5 billion in mid-2017. This was conveyed by Youtube CEO Susan Wojcicki when giving a YouTube brandcast presentation to advertisers (Kompas.com).

A product is perceived as being of quality, if the communication carried out contains a message about this, but it could be a product that actually has many benefits, it may only be perceived as providing little benefit, if the communication does not highlight the benefits of the product. To find out the wants and needs of consumers, there are many influencing aspects such as perceptions, lifestyle, attitudes, culture, social class, reference groups, family and communication. Information received by consumers through communication plays an important role. Wrong communication will affect the success of a communication process. The breadth of the scope of experience and the scope of knowledge of the actors of communication can affect the transfer of symbols. It is possible for a message to be conveyed to be interpreted differently, causing different effects and actions. Message is the essence of a communication, said communication fails if the message cannot be properly understood by the recipient according to the sender's intent.

Consumers' perceptions are also things that can influence brand shifting, therefore positioning is something a company must do in winning the hearts of consumers, in the form of a good impression and good service can increase good credibility in the minds of consumers.

\section{Research Question}

Based on the problems that have been described to clarify the problem, the focus of this research if written in the form of a question is as follows:

1. How does Youtube Advertisement on Grab Service in Bandung?

2. How is the interest in buying Grab Grab in Bandung?

3. How does YouTube influence buy interest in Grab in Bandung?

\section{Research Objective}

Based on this research question that has been described in the Research Question, this research was conducted to:

1. To find out how YouTube advertising affects Grab customers' purchase intentions in Bandung.

2. To find out about asking to buy from Grab in Bandung.

3. To determine the flow of the influence of Youtube ads on customer purchase intentions through the image grab brand.

\section{LiTERATURE REVIEW Advertising $(\mathrm{X})$}

The definition of advertising is non-personal communication about products, ideas, services paid for by sponsors. Non-personal communication means the use of mass media to convey messages to individuals on a large scale. 
Faela Sufa [5] advertising is an information medium that is created in a certain way to attract viewers, is original, and has a specific and persuasive work, so that consumers are motivated to do something according to what advertisers want. Companies not only make good products but they also have to inform consumers about the advantages of their products and carefully position their products in the minds of consumers. Because of this, they must be adept at using promotions. Promotions are aimed at acquiring new customers and retaining existing customers. One of the mass promotion tools is advertising.

Social media itself is defined as an online media, where users can easily participate, share, and create content including blogs, social networks, youtube, wikis, forums and virtual worlds. Andreas Kaplan and Michael Haenlein [15] define social media as a group of internet-based applications that build on the foundation of Web 2.0 ideology and technology, and which enable the creation and exchange of user-generated content. Social media is online media that supports social interaction. Social media uses web-based technology that turns communication into interactive dialogue. Some of the popular social media sites today include: Blog, Twitter, Facebook, Instagram, Path, Wikipedia, Youtube, and so on. According to Van Dijk, social media is a media platform that focuses on the existence of users who facilitate them in activities and collaborations. Therefore, social media is an online facilitator that strengthens relationships between users as well as a social bond.

Youtube is a video site that provides a lot of reliable information in the form of 'moving pictures'. This site is indeed provided for those who want to search for video information and watch it live. We can also participate in uploading videos to Youtube servers and share them around the world. With the Youtube site, the actors who are considered to have a role in global communication, such as broadcasting companies, whether in newspapers, radio or television, seem to have fewer roles. Everyone can broadcast news on Youtube. In fact, there is some news that are only broadcast via Youtube because people are free to upload their own videos. Because the purpose of Youtube is as a place for everyone (no matter their skill level) to upload and share their recording experience with others.

\section{Purchase Intention (Y)}

Zarrad and Debabi [6] define intention as a motivational factor that affects a person's behavior to do something. Kotler and Susanto [7] define intention as one way, namely strong internal stimuli that motivate action, currently inspired by stimuli and positive feelings for the product. Kotler and Keller [8] intention as a decision decision regarding preferences for brands that is in the selection set. Mowen and Minor [9] define intention as all consumer actions to obtain and use goods and services. Lamb et al., [10] defines intention as a customer's process in making and using purchased goods and services. Based on the definition above, it can be denied that intention is anything that encourages someone to act or do something such as buying a product or service.

\section{FRAMEWORK}

Previous research states that currently the media for marketing is developing by following technological developments, indicated by the presence of advertisements through existing social media [11]. Today's social media is increasingly diverse, and one of them is Youtube.

\section{Based on the description above, the hypothesis of this study is as follows}

H0: Advertising via Youtube does not have a significant effect on purchase interest.

H1: Advertising via Youtube has a significant effect on purchase interest.

According to Juliandi [2] that the hypothesis is a conjecture, conclusion or temporary answer to the problem that has been formulated in the previous problem formulation so that the hypothesis is relevant to the problem formulation, namely the temporary answer to the questions that are questioned in the problem formulation. The hypothesis is called temporarily because the actual answers are not yet possible in this section, because no data has been collected by the researcher.

\section{RESEARCH METHODS}

The method used in this research is to use Quantitative methods. This research uses a quantitative research approach in which qualitative research as a scientific method is often used and carried out by a group of researchers in the social sciences, including education. Several reasons are also put forward; the point is that qualitative research enriches the results of quantitative research. A Quantitative research is carried out to build knowledge through understanding and discovery. A quantitative research approach is a process of research and understanding based on methods that investigate social phenomena and human problems. In this study, the researcher created a complex picture, examined the words, detailed reports of the respondents' views and conducted studies on natural situations.

\section{Population and Sample}

According to Sugiyono [12], population is a generalization area consisting of objects/subjects that have certain qualities and characteristics determined by the researcher to study and then draw conclusions. The population in this 
research is Gojek \& Grab transportation in Bandung whose numbers are not known with certainty. The population in this research are customers of Gojek \& Grab transportation in Bandung City whose numbers are not known with certainty, so the sampling technique used is Bernoulli formula. This data is obtained from consumers who feel the influence of communications made by the company through social media YouTube by generating perceptions of the online transportation company's brand. This data is obtained from the results of interviews directly with consumers in the field through online media. From the results of this research, the minimum sample in this research was rounded up to 100 respondents.

\section{RESULTS AND DISCUSSION}

This section contains a description of respondents' identities based on the criteria used in this study including Gender, Age, Last Education, Occupation, Frequency play Youtube in a week, and Frequency of Gojek \& Grab transportation Monthly Uses. The object used in this study is customers of Gojek \& Grab transportation in Bandung City whose numbers are not known certainty. This research use Bernoulli formula to calculate the number of samples, so that a sample of 100 respondents is produced.

The following will describe respondent's identity based on the criteria used in this research including Gender, Age, Last Education, Occupation, Frequency play Youtube in a week, and Frequency of Gojek \& Grab transportation Monthly Uses.

From 100 respondents studied, 39\% of the respondents are Men, and 61\% of the respondents are Women. This indicates that the majority of Gojek \& Grab transportation customers in Bandung City is Woman.

The results supported by the reality that women will choose to use public transportation that is safe and comfortable rather than using private transportation. While, men prefer to use private transportation rather than public transportation. from 100 respondents studied, $26 \%$ of them were 17-23 years old, $43 \%$ of them were 24-28 years old, $25 \%$ of them were 29-34 years old, and 6\% were aged more than 34 years old. This indicates that the majority of Gojek $\&$ Grab transportation customers in Bandung City are aged 24-28 years old.

Basically, 17-23 years old is the age of students, which not many of them already have private transportation, or reconsider the money that must be spent if using private transportation or public transportation. So they choose to use online transportation as their transportation.

\section{Respondents' Identity Based Last Education}

Respondents' identity based on $40 \%$ of them were bachelor graduated, $22 \%$ of them were diploma graduated, $12 \%$ of them were magister graduated, $19 \%$ of them were senior high school graduated and $7 \%$ were other. This indicates that the majority of Gojek \& Grab transportation customers in Bandung City are bachelor graduated. Also from that 100 respondents studied, $16 \%$ of the respondents are use Gojek \& Grab transportation 1-3 times per month, 35\% of the respondents are use Gojek \& Grab transportation 4-5 times per month, 35\% of the respondents are use Gojek \& Grab transportation 6-10 times per month, and 14\% of the respondents are use Gojek \& Grab transportation more than 11 times per month. This indicates that the majority of Gojek \& Grab transportation customers in Bandung City are use Gojek \& Grab transportation about 4-5 and 6-10 times per month

\section{RESEARCH RESUlTS}

After analyzing the respondent's data, the author will then present the research data which is the respondents' answers in the research questionnaire distributed to 100 respondents. The data that have been collected are classified and analyzed using descriptive analysis techniques and simple linear regression analysis. Data are collected using a questionnaire measuring tool with five answer choices, namely: strongly disagree (SD), disagree (D), agree (A), and strongly agree (SA). The number of people who answered strongly agreed is multiplied by 4 (SA x 4 points), agree answer is multiplied by 3 (A x 3 points), disagree answer is multiplied by 2 ( $\mathrm{D}$ x 2 points) and strongly disagree answer is multiplied by 1 ( $\mathrm{SD} x$ points).

\section{Descriptive Analysis}

Descriptive analysis aims to explain the overall data presented by describing, grouping and classifying into a frequency distribution table which is then given an explanation. Descriptive analysis is used to determine the description of youtube advertisements and purchase intention of Gojek and Grab transportation customers in Bandung city from a questionnaire distributed to 100 respondents. The following is an explanation of the results of the respondents' responses.

\section{a) Respondents' responses regarding the variables of youtube advertisements}

The following are the results of the respondents' responses regarding the variables of youtube advertisements obtained from the questionnaire data processing, which can be seen in Table 4.1: 
Table-2: respondents' responses on variables of youtube advertisements (x)

\begin{tabular}{|c|c|c|c|c|c|c|c|c|}
\hline No & Statement & SD & D & $\mathbf{A}$ & SA & Total & Ideal & \multirow{3}{*}{ Category } \\
\hline \multirow[t]{3}{*}{1} & & 1 & 2 & 3 & 4 & Score & Score & \\
\hline & \multirow[b]{2}{*}{$\begin{array}{l}\text { Ads on You tube always provide } \\
\text { New product information }\end{array}$} & 2 & 9 & 42 & 47 & 334 & 400 & \\
\hline & & $2.00 \%$ & $9.00 \%$ & $42.00 \%$ & $47.00 \%$ & \multicolumn{2}{|l|}{$83.50 \%$} & $\begin{array}{l}\text { Very } \\
\text { Good }\end{array}$ \\
\hline \multirow[t]{2}{*}{2} & \multirow{2}{*}{$\begin{array}{l}\text { The message conveyed in the } \\
\text { advertisement on Youtube was able arouse } \\
\text { my desire to know more about online } \\
\text { transportation products }\end{array}$} & 2 & 14 & 40 & 44 & 326 & 400 & \multirow{2}{*}{$\begin{array}{l}\text { Very } \\
\text { Good }\end{array}$} \\
\hline & & $2.00 \%$ & $14.00 \%$ & $40.00 \%$ & $44.00 \%$ & \multicolumn{2}{|l|}{$81.50 \%$} & \\
\hline \multirow[t]{2}{*}{3} & \multirow{2}{*}{$\begin{array}{l}\text { Advertisements about online } \\
\text { transportation always provide information } \\
\text { about new uses }\end{array}$} & 0 & 9 & 60 & 31 & 322 & 400 & \multirow{2}{*}{ Good } \\
\hline & & $0.00 \%$ & $9.00 \%$ & $60.00 \%$ & $31.00 \%$ & \multicolumn{2}{|l|}{$80.50 \%$} & \\
\hline \multirow[t]{2}{*}{4} & \multirow{2}{*}{$\begin{array}{l}\text { The message conveyed by advertisements } \\
\text { on YouTube is able to influence my } \\
\text { decision in determining which online } \\
\text { transportation I use. }\end{array}$} & 7 & 25 & 28 & 40 & 308 & 400 & \multirow[b]{2}{*}{ Good } \\
\hline & & $7.00 \%$ & $25.00 \%$ & $28.00 \%$ & $40.00 \%$ & \multicolumn{2}{|l|}{$77.00 \%$} & \\
\hline \multirow[t]{2}{*}{5} & \multirow{2}{*}{$\begin{array}{l}\text { The message conveyed in the } \\
\text { advertisement on Youtube is able to } \\
\text { influence me in seeing the comparison of } \\
\text { the advantages of each online } \\
\text { transportation product. }\end{array}$} & 3 & 14 & 38 & 45 & 325 & 400 & \multirow[b]{2}{*}{ Good } \\
\hline & & $3.00 \%$ & $14.00 \%$ & $38.00 \%$ & $45.00 \%$ & \multicolumn{2}{|l|}{$81.25 \%$} & \\
\hline \multirow[t]{2}{*}{6} & \multirow{2}{*}{$\begin{array}{l}\text { I think the ads on YouTube About online } \\
\text { transportation are easy to Remember. }\end{array}$} & 2 & 17 & 40 & 41 & 320 & 400 & \multirow[b]{2}{*}{ Good } \\
\hline & & $2.00 \%$ & $17.00 \%$ & $40.00 \%$ & $41.00 \%$ & \multicolumn{2}{|l|}{$80.00 \%$} & \\
\hline \multirow[t]{2}{*}{7} & \multirow{2}{*}{$\begin{array}{l}\text { I think online transportation advertising is } \\
\text { very eye-catching }\end{array}$} & 1 & 14 & 44 & 41 & 325 & 400 & \multirow{2}{*}{ Good } \\
\hline & & $1.00 \%$ & $14.00 \%$ & $44.00 \%$ & $41.00 \%$ & \multicolumn{2}{|l|}{$81.25 \%$} & \\
\hline \multirow[t]{2}{*}{8} & \multirow{2}{*}{$\begin{array}{l}\text { I think ads on YouTube always make a } \\
\text { good impression }\end{array}$} & 7 & 9 & 36 & 48 & 325 & 400 & \multirow{2}{*}{ Good } \\
\hline & & $7.00 \%$ & $9.00 \%$ & $36.00 \%$ & $48.00 \%$ & $81.25 \%$ & & \\
\hline \multicolumn{8}{|c|}{ Total } & 2585 \\
\hline \multicolumn{8}{|c|}{ Average of Youtube Advertisements Variable } & $80.78 \%$ \\
\hline
\end{tabular}

Source: Data that has been processed, 2021

Based on Table 2, it can be described as follows

1) Ads on Youtube always provide new product information

Respondents' responses regarding to the statement above get a percentage of $83.50 \%$. This score is in the very good category. When viewed from the overall responses of respondents, the highest score is obtained by $47.00 \%$ of respondents say they strongly agree, this shows that the respondent is very satisfied with the ads on youtube because always provide new product information.

2) The message conveyed in the advertisement on Youtube was able to arouse my desire to know more about online transportation products

Respondents' responses regarding the statement above get a percentage of $81.50 \%$. This score is in the very good category. When viewed from the overall response of the respondents, the highest score obtained is $44.00 \%$ which states that they strongly agree. This shows that the respondents are very satisfied with the message conveyed in the advertisement on Youtube because able to arouse their desires to know more about online transportation products.

3) Advertisements about online transportation always provide information about new uses Respondents' responses regarding the statement above get a percentage of $80.50 \%$. This score is in the good category. When viewed from the responses of the respondents as a whole, the highest score is obtained by $60.00 \%$ which states that they agree. This shows that the respondents are satisfied with the advertisements about online transportation because always provide information about new uses.

4) The message conveyed by advertisements on YouTube is able to influence my decision in determining which online transportation I use

Respondents' responses regarding the statement above get a percentage of $77.00 \%$. This score is in the good category. When viewed from the overall response of the respondents, the highest score is obtained by $40.00 \%$ which states that they strongly agree. This shows that the respondent is satisfied with the message conveyed by advertisements on youtube because able to influence their decision in determining which online transportation they use. 
5) The message conveyed in the advertisement on Youtube is able to influence me in seeing the comparison of the advantages of each online transportation product

Respondents' responses regarding the statement above get a percentage of $81.25 \%$. This score is in the good category. When viewed from the overall response of the respondents, the highest score is obtained by $45.00 \%$ which states that they strongly agree. This shows that the respondents are satisfied with the message conveyed in advertisement on youtube because able to influence them in seeing the comparison of the advantages of each online transportation product.

6) I think the ads on YouTube about online transportation are easy to remember Respondents' responses regarding the statement above get a percentage of $80.00 \%$. This score is in the good category. When viewed from the responses of the respondents as a whole, the highest score is obtained by $41.00 \%$ which states that they strongly agree. This shows that the respondents are satisfied because the ads on youtube about online transportation are easy to remember.

7) I think online transportation advertising is very eye -catching

Respondents' responses regarding the statement above get a percentage of $81.25 \%$. This score is in the good category. When viewed from the overall response of the respondents, the highest score is obtained by $44.00 \%$ which stated that they agree. This shows that the respondents are satisfied because online transportation advertising is very eye-catching.

8) I think ads on YouTube always make a good impression

Respondents' responses regarding the statement above get a percentage of $81.25 \%$. This score is in the good category. When viewed from the responses of the respondents as a whole, the highest score obtained is $48.00 \%$ which states that they strongly agree. This shows that the respondents feel satisfied because the ads on YouTube always make a good impression.

The following are the results of the respondents' responses regarding the variables of purchase intention obtained from the questionnaire data processing, which can be seen in

Table-3: Respondents' responses on variables of purchase intention

\begin{tabular}{|c|c|c|c|c|c|c|c|c|}
\hline \multirow{2}{*}{ No } & \multirow{2}{*}{ Statement } & \multirow{2}{*}{ SD } & \multirow{2}{*}{ D } & \multirow{2}{*}{$\mathbf{A}$} & SA & Total & Ideal & \multirow{2}{*}{ Category } \\
\hline & & & & & 4 & Score & Score & \\
\hline \multirow{2}{*}{1} & \multirow{2}{*}{$\begin{array}{l}\text { I use online transportation } \\
\text { services because of the } \\
\text { interesting ads on Youtube }\end{array}$} & 0 & 11 & 34 & 55 & 344 & 400 & \multirow{2}{*}{$\begin{array}{l}\text { Very } \\
\text { Good }\end{array}$} \\
\hline & & $0.00 \%$ & $11.00 \%$ & $34.00 \%$ & $55.00 \%$ & \multicolumn{2}{|l|}{$86.00 \%$} & \\
\hline \multirow[b]{2}{*}{2} & \multirow{2}{*}{$\begin{array}{l}\text { I use online transportation } \\
\text { services because there is no } \\
\text { other more convenient } \\
\text { transportation option }\end{array}$} & 1 & 14 & 38 & 43 & 323 & 400 & \multirow[b]{2}{*}{ Good } \\
\hline & & $1.00 \%$ & $14.00 \%$ & $40.00 \%$ & $43.00 \%$ & \multicolumn{2}{|l|}{$80.75 \%$} & \\
\hline \multirow[b]{2}{*}{3} & \multirow{2}{*}{$\begin{array}{l}\text { I Use online transportation } \\
\text { services because it is } \\
\text { wellknown to the public }\end{array}$} & 2 & 8 & 47 & 43 & 331 & 400 & \multirow{2}{*}{$\begin{array}{l}\text { Very } \\
\text { Good }\end{array}$} \\
\hline & & $2.00 \%$ & $8.00 \%$ & $47.00 \%$ & $43.00 \%$ & \multicolumn{2}{|c|}{$82.75 \%$} & \\
\hline \multirow{2}{*}{4} & \multirow{2}{*}{$\begin{array}{l}\text { I use online transportation } \\
\text { because I need it services }\end{array}$} & 2 & 14 & 48 & 36 & 318 & 400 & \multirow{2}{*}{ Good } \\
\hline & & $2.00 \%$ & $14.00 \%$ & $48.00 \%$ & $36.00 \%$ & \multicolumn{2}{|l|}{$79.50 \%$} & \\
\hline \multirow[b]{2}{*}{5} & \multirow{2}{*}{$\begin{array}{l}\text { I use online transportation } \\
\text { services because there is no } \\
\text { more convenient transportation }\end{array}$} & \multirow[b]{2}{*}{$33.00 \%$} & \multirow{2}{*}{$\begin{array}{l}10 \\
10.00 \%\end{array}$} & 37 & 50 & 334 & 400 & \multirow{2}{*}{$\begin{array}{l}\text { Very } \\
\text { Good }\end{array}$} \\
\hline & & & & $37.00 \%$ & $50.00 \%$ & \multicolumn{2}{|l|}{$83.50 \%$} & \\
\hline \multirow{4}{*}{6} & \multirow{3}{*}{$\begin{array}{l}\text { I use online transportation } \\
\text { services because they are cheap, } \\
\text { safe, and practical }\end{array}$} & 1 & 9 & 37 & 53 & 342 & 400 & \multirow{2}{*}{$\begin{array}{l}\text { Very } \\
\text { Good }\end{array}$} \\
\hline & & $1.00 \%$ & $9.00 \%$ & $37.00 \%$ & $53.00 \%$ & \multicolumn{2}{|l|}{$85.50 \%$} & \\
\hline & & & \multirow{2}{*}{\multicolumn{5}{|c|}{ Total }} & 1992 \\
\hline & \multicolumn{2}{|c|}{ Average of Youtube Advertisements Variable } & & & & & & $83.00 \%$ \\
\hline
\end{tabular}

Source: Data that has been processed, 2021

\section{Based on Table 4.2, it can be described as follows}

1 I use online transportation services because of the interesting ads on Youtube Respondents' responses regarding to the statement above get a percentage of $86.00 \%$. This score is in the very good category. When viewed from the overall responses of respondents, the highest score is obtained by $55.00 \%$ of respondents say they strongly agree, 
this shows that the respondent is very satisfied to use online transportation services because of the interesting ads on Youtube

2 I use online transportation services because there is no other more convenient transportation option

Respondents' responses regarding the statement above get a percentage of $80.75 \%$. This score is in the good category. When viewed from the overall response of the respondents, the highest score obtained is $43.00 \%$ which states that they strongly agree. This shows that the respondents are satisfied to use online transportation services because there is no other more convenient transportation option.

\section{I use online transportation services because it is well known to the public}

Respondents' responses regarding the statement above get a percentage of $82.75 \%$. This score is in the very good category. When viewed from the responses of the respondents as a whole, the highest score is obtained by $87.00 \%$ which states that they agree. This shows that the respondents are very satisfied to use online transportation services because it is well known to the public.

\section{I use online transportation because I need it services}

Respondents' responses regarding the statement above get a percentage of $79.50 \%$. This score is in the good category. When viewed from the overall response of the respondents, the highest score is obtained by $48.00 \%$ which states that they agree. This shows that the respondent is satisfied to use online transportation because they need it services.

5 I use online transportation services because there is no more convenient transportation Respondents' responses regarding the statement above get a percentage of $83.50 \%$. This score is in the very good category. When viewed from the overall response of the respondents, the highest score is obtained by $50.00 \%$ which states that they strongly agree. This shows that the respondents are very satisfied to use online transportation services because there is no more convenient transportation.

6 I use online transportation services because they are cheap, safe, and practical Respondents' responses regarding the statement above get a percentage of $85.50 \%$. This score is in the very good category. When viewed from the responses of the respondents as a whole, the highest score is obtained by $53.00 \%$ which states that they strongly agree. This shows that the respondents are very satisfied to use online transportation services because they are cheap, safe and practical. To see the average value of all respondents' responses to the job satisfaction variable (X) which category is in, it can be shown on the continuum line below: it can be seen that the overall purchase intention variable $(\mathrm{X})$ on the continuum line is in the very good category with a percentage value of $83.00 \%$. With this percentage, it means that the purchase intention of Gojek and Grab transportation customers are in the very good category.

\section{Method of Successive Internal (MSI)}

Before being processed with simple regression, the data in the ordinal scale obtained by using the Likert scale first, the data is transformed into an interval scale using the Method of Successive Interval (MSI). Processing of ordinal data into intervals is done by using Microsoft Excel, the results of the MSI conversion can be seen in the MSI conversion attachment.

\section{Classic Assumption Test}

a) Normality Test

This test aims to see and find out whether a regression model is normally distributed or not, because a good regression model has a residual value that is normally distributed (According to Silalahi [13]. The normality of data can be determined through the P-Plot and histogram graphs, with the following decision criteria:

1) The data is said to be normally distributed, if the data spreads around the diagonal line and follows the direction of the histogram line. Then the regression model fulfills the classic assumptions.

2) Conversely, the data is said to be not normally distributed, if the data spreads far from the direction of the line or does not follow the diagonal or histogram graph. Then the regression model does not meet the classic assumptions

The results of the normality test in Figure 4.9 can be concluded that the overall data used to measure the purchase intention variable has been normally distributed. To further ensure that apart from using the P-P plot, the normality test can also be done with the Kolmogorov-Smirnov (K-S) with a significant level $(\alpha)$ of 0.05 . If the significant value is higher than 0.05 , it means that the data is normally distributed. It can be seen in Table 4.3 below: 
Table-4: normality test results One-Sample Kolmogorov-Smirnov Test

\begin{tabular}{|l|l|l|}
\hline \multicolumn{2}{|l|}{} & $\begin{array}{l}\text { Unstandardiz ed Predicted } \\
\text { Value }\end{array}$ \\
\hline $\mathrm{N}$ & & 100 \\
\hline \multirow{2}{*}{ Normal Parameters } & Mean & 3.5249200 \\
\hline \multirow{2}{*}{ Most Extreme } & $\begin{array}{l}\text { Std. } \\
\text { Deviation }\end{array}$ & .33947866 \\
\hline \multirow{2}{*}{ Differences } & Absolute & .105 \\
\cline { 2 - 3 } & Positive & .066 \\
\hline Kolmogorov-Smirnov Z & Negative & -.105 \\
\hline Asymp. Sig. (2-tailed) & & 1.055 \\
\hline
\end{tabular}

a. Test distribution is Normal.

b. Calculated from data.

Source: Data that has been processed, 2021

Based on Table 4 above, the Kolmogorof-Smirnov test results show that the data shows a significant value higher than alpha $(0.216>0.05)$. Therefore, it can be concluded that the data for all variables are normally distributed. The Kolmogorof-Smirnov test is only to strengthen the reading of the histogram and normality graphs previously described [16].

\section{Simple Linear Regression Analysis}

The inferential analysis method used in this research is Simple Regression Analysis. Simple linear regression analysis is used to find the effect of independent variables on the dependent variable directly.

Based on the results of data processing using SPSS software, the following results are obtained:

Table-5: Simple linier regression analysis

\begin{tabular}{|l|l|l|l|l|l|l|}
\hline \multicolumn{2}{|c|}{} & Coefficients $^{\text {a }}$ & \multicolumn{2}{l|}{} \\
\hline \multicolumn{2}{|c|}{ Model } & Unstandardized & Coefficients & Standardized Coefficients & t & Sig. \\
\hline \multicolumn{2}{|c|}{} & B & Std. Error & Beta & & \\
\hline \multirow{2}{*}{1} & (Constant) & 1.521 & & & 5.519 & .000 \\
\cline { 2 - 7 } & Advertising & .597 & .081 & .597 & 7.376 & .000 \\
\hline
\end{tabular}

a. Dependent Variable: Purchase Intention

Source: Data that has been processed, 2021

\section{Based on Table 5, the following regression models can be obtained}

$\mathbf{Y}=\mathbf{a}+\mathbf{b} \mathbf{X}$

$Y=\mathbf{1 , 5 2 1}+\mathbf{0 , 5 9 7 X}$

The constant value a means that when youtube advertisements $(\mathrm{X})$ are zero $(0)$ or purchase intention $(\mathrm{Y})$ is not influenced by work satisfaction, the average of youtube advertisements is 1.521 . While the regression coefficient $b$ means that if the variable of purchase intention $(\mathrm{X})$ increases by one unit, the variable of youtube advertisements (Y) will increase by 0.597 . The regression coefficient is positive, which means that youtube advertisements has a positive effect on purchase intention (the higher/stronger the youtube advertisements, the higher the purchase intention) [17].

\section{Hypothesis Test (F-Test)}

The simultaneous test (F test) is used to test jointly whether or not the influence of the independent variables on the dependent variable can be determined by using the F test. Then there is a significant effect or Ho is rejected and Ha is accepted. The results show the following table. 
Table-6: $t$ test results $\mathrm{ANOVA}^{\mathrm{a}}$

\begin{tabular}{|l|l|l|l|l|l|l|}
\hline Model & & Sum of & df & Mean & F & Sig. \\
\hline & & Squares & & Square & & \\
\hline & Regression & 11.409 & 1 & 11.409 & 54.408 & $.000^{\mathrm{b}}$ \\
\hline 1 & Residual & 20.551 & 98 & .210 & & \\
\hline & Total & 31.960 & 99 & & & \\
\hline
\end{tabular}

a. Dependent Variable: Purchase Intention

b. Predictors: (Constant), Advertising

Source: Data that has been processed, 2021

Based on the table above, it can be seen that the significance value (Sig.) In the F test is 0.000. Because Sig $0.000<0.05$, as the basis for decision making in the $\mathrm{F}$ test, it can be concluded that youtube advertisement $(\mathrm{X})$ has an effect on purchase intention (Y) or it means significant.

\section{Coefficient Determination}

The calculation of the coefficient of determination is assisted by SPSS 20 in Table 4.6 as follows:

Table-7: Determination coefficient model summary ${ }^{b}$

\begin{tabular}{|c|c|c|c|c|c|c|c|c|c|c|}
\hline & & & & & \multirow{2}{*}{\multicolumn{5}{|c|}{ Change Statistics }} & \multirow[b]{3}{*}{$\begin{array}{l}\text { Durbin- } \\
\text { Watson }\end{array}$} \\
\hline \multirow[b]{2}{*}{ Model } & \multirow[b]{2}{*}{$\mathbf{R}$} & \multirow[b]{2}{*}{$\begin{array}{l}\mathbf{R} \\
\text { Square }\end{array}$} & \multirow{2}{*}{$\begin{array}{l}\text { Adjusted } \\
\mathbf{R} \\
\text { Square }\end{array}$} & \multirow{2}{*}{$\begin{array}{l}\text { Std. } \\
\text { Error } \\
\text { of the } \\
\text { Estimate }\end{array}$} & & & & & & \\
\hline & & & & & $\begin{array}{l}\mathbf{R} \\
\text { Square } \\
\text { Change }\end{array}$ & $\begin{array}{l}\text { F } \\
\text { Change }\end{array}$ & df1 & df2 & $\begin{array}{l}\text { Sig. F } \\
\text { Change }\end{array}$ & \\
\hline 1 & $.597^{\mathrm{a}}$ & .357 & .350 & .45793 & .357 & 54.408 & 1 & 98 & .000 & 1.964 \\
\hline
\end{tabular}

a. Predictors: (Constant), Advertising

b. Dependent Variable: Purchase Intention

Based on Table above, it shows the amount of youtube advertisement with purchase intention as indicated by the acquisition of the correlation coefficient ( $r$ ) of 0.597 . The magnitude of the influence of youtube advertisement on purchase intention is shown by the coefficient of determination with the following formula:

$=\%$

$=0.375100 \%$

$=35.7 \%$

The coefficient of determination from the calculation results is $35.7 \%$. This shows that work satisfaction has an effect of $35.7 \%$ on purchase intention, while the remaining $64.3 \%$ is influenced by other variables not examined in this study.

\section{CONCLUSION}

Based on the results of research and discussion on "The Effect of Youtube Advertisement on Customers' Purchase Intention of Online Transportation Brands in Bandung (Case Study on Grab and Gojek Companies" it can be concluded as follows:

a Youtube advertisements on customers of Gojek and Grab transportation in Bandung city is in the good category with percentage of $80.78 \%$.

b Purchase intention on customers of Gojek and Grab transportation in Bandung city is in the very good category with percentage of $83.00 \%$.

c Youtube advertisements and purchase intention has a low level of correlation and a coefficient of determination of $35.7 \%$, but it is estimated that per unit increase in youtube advertisements variable, it will increase 0.597 units in the purchase intention variable based on regression model.

\section{REFERENCE}

1. Miro, F. (2012). Introduction to Transportation Systems, Jakarta: Erlangga.

2. Azuar, J. (2013). Metodelogi Penelitian Kuantitatif: untuk ilmu-ilmu Bisnis. Medan: M2000

3. Nielsen, J. (2012). How Many Test Users in a Usability Study? https://www.nngroup.com/articles/how-many-testusers/

4. Bernoff, J., \& Charlene, L.I. (2011). Groundswell; winning in a world transformed by social technologies. Forrester Research. USA

5. Sufa, F., Dan, B. Munas. (2012). “analisis pengaruh iklan, kualitas iklan pesan iklan, frekuensi iklan terhadap efektifitas manajemen iklan mie sedap, 1(4), 226-233. 
6. Zarrad, H., \& Debabi, M. (2015). Analyzing the effect of electronic word of mouth on tourists' attitude toward destination and travel intention. International research journal of social sciences, 4(4), 53-60.

7. Kotler, P., \& Susanto, A. B. (2010). Marketing Management in Indonesia.

8. Kotler., \& Keller. (2012). Marketing Management. 12. Jakarta Edition: Erlangga

9. Mowen, J.C., \& Minor, M. (2012). Consumer Behavior. Volume 1 and volume 2. Edition 5. Translated by: Dwi Kartini Yahya. Jakarta: Erlangga. Salemba.

10. Lamb, H., \& Mcdaniel. (2012). Marketing, First Edition, Jakarta: Salemba Empat

11. Barhemmati, N., \& Ahmad, A. (2015). Pengaruh Pemasaran Jaringan Sosial (SNM) terhadap Perilaku Pembelian Konsumen melalui Keterlibatan Konsumen. Jurnal Manajemen Muka, 1-5.

12. Sugiono, (2018). Metode Penelitian Kuantitatif, Kualitatatif dan R\&D. Bandung: CV. Alfabeta.

13. Silalahi, U. (2015). Metode Penelitian Sosial. Bandung: PT. Refika Aditama

14. Indrawati. (2015). Metode Penelitian Manajemen dan Bisnis Konvergensi Teknologi Komunikasi dan Informasi, Bandung: Aditama.

15. Kaplan, Andreas. M., \& Haenlein, M. (2010). Users of the world unite! The challenges and opportunities of Social Media. Business Horizon.

16. Pradana, M. (2015). Pengaruh Gaya Kepemimpinan Terhadap Motivasi Karyawan di Ganesha Operation, Bandung. Jurnal Studi Manajemen dan Bisnis, 2(1), 24-39.

17. Pradana, M., \& Novitasari, F. (2017). Gap analysis of Zalora online application: Indonesian users' perspectives. International Journal of Learning and Change, 9(4), 334-347.

CITATION: Mahir Pradana \& Irfan (2021). The Effect of Youtube Advertisement on Consumer Purchase Intention of Online Transportation Brands In Bandung (Case Study on Grab and Gojek Companies). South Asian Res J Eng Tech, 3(2): 44-54. 